\title{
The Current State of Religious Education in Russia by the Example of Comprehensive Schools and Higher Educational Institutions of Rostov-on-Don
}

\author{
Igor Grekov ${ }^{1}$, and Olga Orlenko ${ }^{*}$ \\ 1 Ryazan State University named for S. Yesenin, department "Philosophy", 390000 \\ Ryazan, Russian Federation \\ 2 Don State Technical University, "Philosophy and World Religions" department, \\ 344000 Rostov-on-Don, Russian Federation
}

\begin{abstract}
In the article there is a judgment of the current state of religious education in Russia by the example of comprehensive schools and higher education institutions of Rostov-on-Don. The authors mark a number of problems preventing high-quality improvement of religious education in the Russian Federation and also speak about the achievements in this sphere made lately. In the article the need of improvement of quality of religious education in Russia contacts a huge number of destructive information in the Internet space and its adverse effect on the modern Russian youth and also the substitution of real life by virtual reality and the related with them falling of the intellectual level of development of the young generation which has received the manifestation in ignorance of history and culture of their own country. The authors argue about the changes of the meaning of the category "value" in the modern Russian society. They compare modern understanding of "value" with understanding of "value" of the beginning of the 20th century. A set of traditional cultural values is given in the article, it is necessary to impart these values to the young generation to protect it from the adverse effect of the Internet space and to develop the critical relation to the obtained information.
\end{abstract}

\section{Introduction}

Carrying out the search of necessary data for educational or work activity in the Internet space, daily the modern person is forced to face a flow of collateral unnecessary or even harmful information the purpose of which is to draw attention by shocking of the user. The Internet space contains scenes of cruelty of the person in relation to other people and animals, demonstration of acts of vandalism in relation to the monuments of history of mankind, promotion of suicide and terrorism, consecration of dangerous experiments of the

\footnotetext{
* Corresponding author: osya8923@yandex.ru
} 
person with his own life and health and also a large number of other destructive information which, despite the attempts of its elimination by the relevant government services, nevertheless, has negative impact on the person.

Pupils of schools and students of higher education institutions which owing to their age and lack of certain life experience just cannot critically perceive the information obtained by them are especially susceptible to the information of this sort, and for some of them the virtual space of a game completely replaces their real life. If earlier school students preferred to spend time between the lessons playing outdoor games and communicating with their schoolmates, then now all their attention is riveted on games and accounts in social networks, an access to which practically each of them has in their phones. According to the data of All-Russian Public Opinion Research Center, young people of student's age spend especially much time in space of social networks "91\% of young people at the age of 18-24 almost daily use social networks" [1]. Such enthusiasm for virtual reality is dangerous for the young man, it is recognized also by the famous Russian science fiction writer S. Lukyanenko who considers that only religion is capable to resist the artificial reality created by the person: "But, perhaps, the most powerful anchor is a belief, a Church. The real spiritual life helps the person to cope with temptation of virtuality with its "absolute" freedom" [2].

As at the present stage of the development of our society it is impossible to make a refusal of use of social networks, and of the Internet space in general, that the orthodox church represented by the Patriarch of All Russia Kirill recognizes: "Blogs, social networks, all this gives new opportunities for the Christian certificate. Not to be present there means to admit own helplessness and not zeal about rescue of fellows. Now, when a huge interest is shown to the church life in social media, though not always healthy, our debt is to turn it for the good, to create conditions in order that the youth knew about Christ, knew the truth about the life of the people of Church" [3]. A lot of things according to the Patriarch of All Russia Kirill depend on that in whose hands there will be this or that information: "Internet can be a unique tool of the report to the person of a church sermon, the intermediary in real-life communication with the neighbor who is in the distance, the conductor to the liturgical life of Church" [4]. The main task is a high-quality improvement of religious education in Russia as one of ways of spiritual fight against the influence of destructive information on the Internet. But to improve educational process qualitatively, in general, it is necessary to begin with school at which traditional cultural values are put, in view of the fact that the category of "value" undergoes significant changes in modern Russia caused by influence of postmodern culture.

\section{Results and discussion}

The definition of spiritual value and a set of cultural values were formulated and received the description in works of such outstanding religious thinkers of the 19-20th centuries: V.S. Solovyov, P.A. Florensky, S.N. Bulgakov, N.A. Berdyaev, S.L. Frank, B.P. Vysheslavtsev, N.O. Lossky. The Russian religious philosophers of that time understood a reference point of spiritual and moral improvement of the person directed to his rapprochement with God as spiritual value. An ideal of spiritual improvement of the person, Jesus Christ was recognized as the creator of other cultural values and at the same time as the supreme spiritual value. However, over time the concept of "value" of Russia begins to be treated not as spiritual and moral improvement of the person but as anything that represents the importance for him at present, but, what represents the importance for one person, can mean nothing for another. Therefore, it is obviously important for spiritual safety of the young generation to impart traditional cultural values which are accepted by most of members of society to the young generation. These are such values as 
the value of human person, of human life, of freedom, of love, of work, of family and of creativity.

The major step toward the high-quality improvement of religious education in Russia was taken in 2002 when the Ministry of Education of the Russian Federation included the subject "Orthodox Culture" (the enclosure of the Ministry of Education of the Russian Federation of 22.10.2002 No. 14-52-876 in/16) into the curriculum of comprehensive school and "developed the corresponding educational methodological support of the subject" [5] that became the beginning of high-quality improvement of religious education in Russia. Textbooks and education guidances of A. Kurayev and L. Shevchenko's, and of other authors appeared. However, already at this stage of high-quality improvement of religious education in Russia there were several problems for implementation of this program, the main from which was a shortage of qualified personnel. Lessons of "Orthodox culture" and of "The bases of religious cultures and secular ethics" at comprehensive school often have nominal character as they are conducted by the experts from other areas of school knowledge having sometimes very superficial idea of traditional values, of orthodox culture and of cultures of other people of the world the knowledge of which would allow them to show specifics of culture and history of Russia. The shortage of qualified personnel is the cause of the appearance of such problem, trying to fill this gap in the system of religious education, the administration of comprehensive schools makes the decision to intrust teaching of the lessons of "Orthodox culture" and of "'The bases of religious cultures and secular ethics" to the teachers of subjects of a natural-science profile (biology, physics, chemistry) and also to the teachers of such subjects as technology, drawing and physical culture, at best to the teachers of Russian and literature or history and social science. The need for competent experts of this area of school knowledge received the manifestation in emergence of a set of vacancies in the different settlements of Russia, for example, "according to the popular websites of work for the last 30 days in Rostov-on-Don 480 vacancies of profession positions "The teacher of the bases of orthodox culture" have been opened [6].

Great attention is paid to training of teachers of "Orthodox culture" in DSTU where training according to the program of professional retraining "The orthodox educational psychologist" by "Orthodox Culture and Theology" department is carried out. "Development of this course will allow the priests and the teachers of the Sunday and comprehensive schools (who does not have profile education) and also the parents to receive qualification "educational psychologist" for work in the educational organization, to gain necessary theoretical and practical experience of the organization of educational activity with children in the family, in the parish, in the educational organization" [7]. One more department of DSTU "Philosophy and World Religions" carries out training of graduate students in the specialty 09.00 .14 (philosophy of religion and religious studies). At present training of specialists in the specialty 48.03.01 (theology) is also conducted at "Philosophy of Religion and Religious Studies" department on the basis of Institute of Philosophy and Socio-political Sciences of Southern Federal University.

Teachers of "The bases of Orthodox culture" or of "The bases of religious cultures and secular ethics" face one more pressing problem at modern school, it is a shortage of the equipment or its inadequate state, which would allow to visualize giving of a training material as much as possible. The specifics of the subjects "The bases of Orthodox culture" and "The bases of religious cultures and secular ethics" assume the use of a large amount of visual material, it can be images of icons, temples, sculptures, pictures, display of the presentations, fragments of telecasts, animated films and feature films of orthodox theme. For example, the display of the animated film from the cycle "Stories of the Old Testament" when the teacher tells the pupils about the parts of the Bible or some fragment from the animated film "Knyaz Vladimir" when the teacher talks about the Christianization 
of Kyivan Rus' at the lesson. However, the equipment which is available at schools: a projector, musical columns, a screen are often totally out of whack, and the teachers should manage without it, that does not allow the pupils to digest the training material fully.

The teachers of "The bases of orthodox culture" or of "The bases of religious cultures and secular ethics" face one more certain problem, it is the negative attitude to these lessons of the pupils' parents which being unfamiliar with the program of these subjects, consider that their teaching is connected with learning of prayers and fragments from the Bible, with the studying of theology while the aim of knowledge of these subjects is to study history and culture of the country in which their children live and study. The priest Pavel Ostrovsky answers the question: "How exactly should the teachers work with negatively predisposed parents?" He says: "It is necessary to use all opportunities for communication with the pupils` parents. For example, the teachers should go to the teacher-parent meetings and speak there: for certain you have questions about my subject, for certain the relation is ambiguous, let's find an opportunity to meet, we will discuss pluses and minuses if you want, we will invite the priest ..." [8].

In recent years the urgent need in increase in qualitative level of spiritual education of students of higher education institutions of Russia also appeared. The courses of educational character begin to disappear from technical colleges of Russia, through these courses students could learn about traditional cultural values of Russia, deepen the knowledge in the field of secular ethics, develop the critical relation to the obtained information. For the solution of this problem "the creation of departments of orthodox culture and theology in a number of the universities, including in DSTU, teaching disciplines of "The morality basis", "The bases of Orthodox culture", "Spiritual and moral fundamentals of world religions" in higher educational institutions of the country" is of paramount value [9] and also the inclusion of religious subject close to the contents of religious studies courses: philosophies, linguistics, pedagogics, psychology, law. Besides the called subjects in DSTU the following courses are given: religious studies, world religions, religion and policy and many other courses of religious orientation.

High-quality improvement of religious education in Russia has to promote increase in intellectual level of modern Russian students as the last researches demonstrate bad knowledge of young people of world history and history of Russia, so, according to the professor of "Sociology and Theology" department of Humanitarian Institute of the North Caucasian Federal University. A.A. Lagunova, the historical and religious and educational "educational program" is necessary for modern students" as they do not know history of relationship of the state and church in Russia" [10]. The crucial role in development among students of higher education institutions of the critical relation to the perceived information is played by their will, ability to listen to the point of view of other people and to express their own position on this or that question well-reasoned.

\section{Conclusions}

Thus, the activity for instilling of traditional cultural values through teaching religious disciplines at comprehensive schools and at higher education institutions of Russia can be considered as a security measure from destructive information in the Internet space. If the circle of such disciplines at school is not big and if it includes only two subjects: "The bases of Orthodox culture" or "The bases of religious cultures and secular ethics", then it is wider at higher education institution and it also includes both the creation of departments, for example "Orthodox Culture and Theology", "Philosophy and World Religions" and the reading of theological courses including "Religious and secular ethics" and also the inclusion of moral problems of religions into the courses of a humanitarian cycle.

The main problems getting in the way of teaching of "The bases of Orthodox culture" 
and of "The bases of religious cultures and secular ethics" at school consist in the shortage of qualified personnel, in the absence of equipment for display of video of materials to pupils or its workless condition, in bad knowledge of pupils ' parents of the content of these subjects at school and also in the changes connected with understanding of the category "value" in modern Russian society. At higher education institutions such problems are the refusal of inclusion into the curricula of courses of theological character as having minor character and also the absence in working programs of humanitarian subjects touching the main problems of religious and secular ethics. However, significant steps on the way of formation of religious education at comprehensive schools and at higher education institutions of Russia have been already made that is confirmed by the existence of textbooks, education guidances and methodical recommendations and also by the significant amount of audio and video materials which both the teacher of comprehensive school and the teacher of higher education institution can use in the work.

\section{References}

1. The popularity of social networks in Russia depends on age. The poll. https://regnum.ru/news/society/2379117.html

2. V. Kaplan, Temptation by virtual reality (2006) https://foma.ru/iskushenie-virtualnojrealnostyu.html

3. The mission in virtual space cannot substitute the parish work, but has to supplement it, the Head of the Russian Church emphasized. https://pravoslavie.ru/59208.html

4. T. Matiash, "... I feel power!" Internet as a new measurement in the parochial space. Interview with the celibate priest Makari (Markish). https://pravoslavie.ru/47476.html

5. F. Kozyrev, Methodological resources of improvement of quality of teaching of religion at high school.

6. About the profession of a teacher of "The bases of Orthodox culture". https://rostov.postupi.online/vuz/dgtu/professiya/uchitel-osnov-pravoslavnoj- kultury/

7. In DSTU there is a set of students on training in the program of professional retraining "The orthodox educational psychologist". http://rostoveparhia.ru/eparkhijasegodnja/eparkhialnye-otdely/otdel-religioznogo-obrazovanija-i-katehizacii/v-dgtuosushchestvlyaetsya-nabor-na-obuchenie-po-programme-professionalnoy- perepodgotovkipravoslavn/

8. V. Kaplan, How to teach "The bases of Orthodox culture". https://foma.ru/kak-prepodavatopk.html

9. T. Olenich, A. Koriakin, Scientific works of the Don theological seminary with participation of "Orthodox Culture and Theology" department of the Don State Technical University: collection. Rostov-on-Don, DSTU, 144-152 (2018)

10. A. Lagunov, Space and time. 4(10), 126-128, (2012) 